\section{LENGTH - WEIGHT RELATIONSHIP OF FEATHER BACK, NOTOPTERUS NOTOPTERUS (PALLAS) FROM JANNAPURA POND, KARNATAKA, INDIA}

\section{B.R. Kiran, E.T. Puttaiah and K. Harish Kumar}

Department of Environmental Science, Kuvempu University, Shankaraghatta, Karnataka 577451, India.

Notopterus notopterus (Pallas) commonly known as 'Chamari meenu' in Karnataka is widely distributed in ponds, pools, lakes, tanks and reservoirs of India. Notopterus notopterus is included in the suborder Notopteroidei under the order Osteoglassiformes and family Notopteridae. It is a popular food for economically weak communities because of low price. It has enormous potential for high productivity and is known for its nutritive and therapeutic qualities. No attempt has been made to study the life history of this species in the Malnad regions of Karnataka. The length-weight relationship is essential to establish growth equation in production and to know if the fishes maintain a constant body shape throughout their life span.

Notopterus notopterus specimens were collected from August 2002 to February 2003 from Jannapura Pond (13 $45^{\prime} 00^{\prime \prime N}$ \& $75^{\circ} 30^{\prime} 14^{\prime \prime E}$ ), situated $20 \mathrm{~km}$ away from Kuvempu University campus. The pond receives water from Bhadra Reservoir left bank channel and sewage from residential settlements.

A total of 53 specimens of Notopterus notopterus were examined ( 22 were males and 31 females); total length and total weight were recorded; body weight was taken using an electronic balance; and length from snout to tip of the caudal fin was measured following standard method (Choudhary et al., 1975).

The least square method was adopted to determine the lengthweight relationship and actual length-weight data were converted to their respective log value for calculation (Fig. 1). The relationship obtained from the data are as follows:

Males: $\log \mathrm{W}=-2.4997+3.2721 \log \mathrm{L}$ or $\mathrm{W}=0.003164 \mathrm{~L}^{3.2721}$ Females: $\log \mathrm{W}=-1.8865+2.8483 \log \mathrm{L}$ or $\mathrm{W}=0.01298 \mathrm{~L}^{2.8483}$

The correlation coefficient (r) was 0.8040 and 0.8629 for male and female respectively which is higher than the tabulated ' $r$ ' value (Pauly, 1983) at n-2 degree of freedom at 1\% level of probability. From the F-ratio, there is significant difference between two regression equations for both the sexes at n-2 degree of freedom at $5 \%$ probability level. The specimens had a length range of 19.1 to $33.8 \mathrm{~cm}$ and weight range of 56.0 to $358.4 \mathrm{~g}$ respectively. The calculated ' $\mathrm{t}$ ' value was higher than tabulated value at $5 \%$ probability level for both the sexes. Parameswaran and Sinha (1966) recorded maximum length of $40 \mathrm{~cm}$ in Notopterus notopterus whereas in the present study
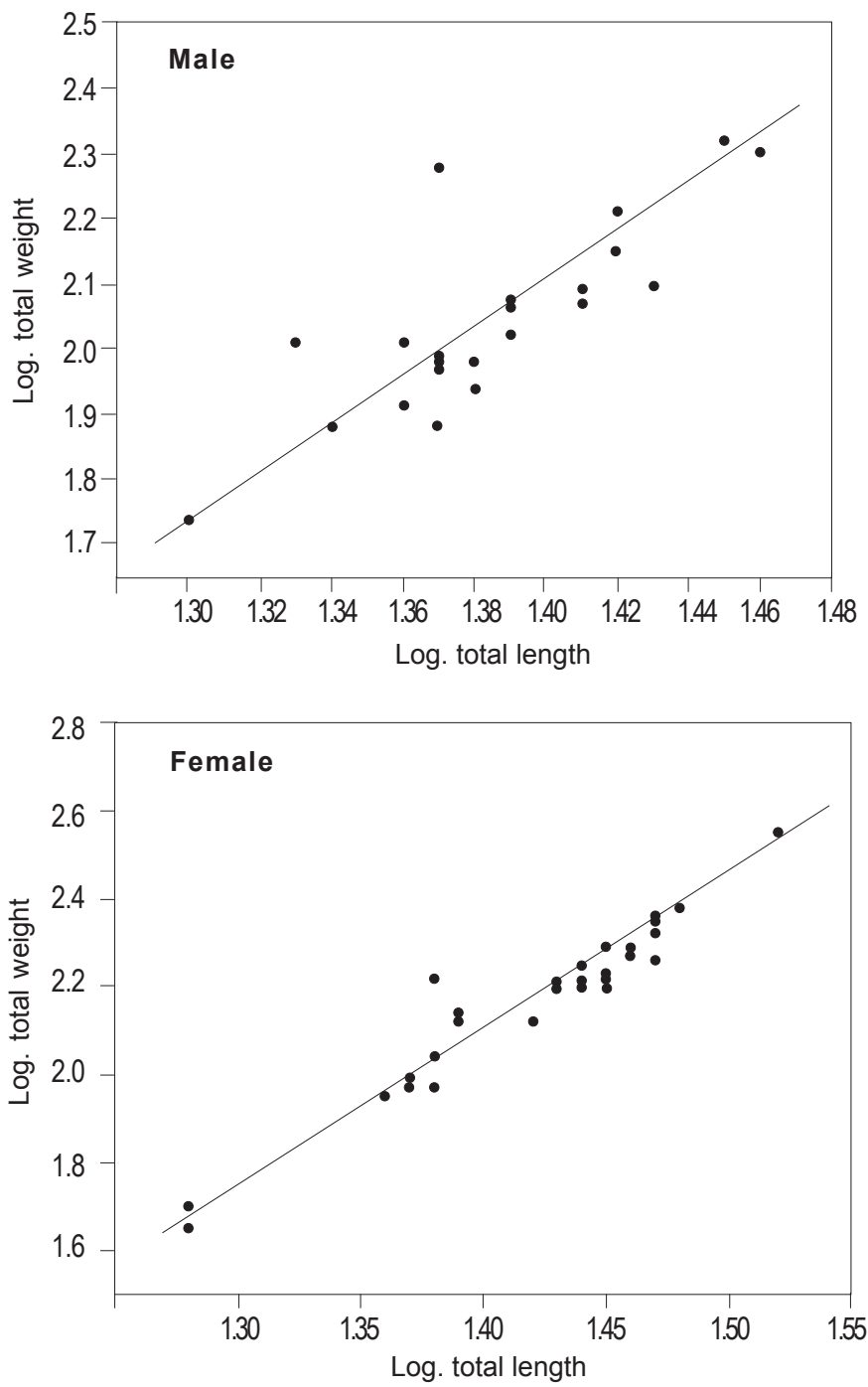

Figure 1. Logarithmic relationship between length-weight of Notopterus notopterus

the maximum length recorded in female Notopterus notopterus was $33.8 \mathrm{~cm}$. Hamza (1980) reported linear relationship in Notopterus notopterus with length ranging from $13-13.5 \mathrm{~cm}$ and weight $14-400 \mathrm{~g}$.

In the present investigation, the length ranging from $\log 1.28$ to $1.48 \mathrm{~cm}$ with weight ranging from $\log 1.74$ to $2.55 \mathrm{~g}$ showed a linear relationship indicating that when length increases; the corresponding weight also increases proportionately. Hence, the present study is in agreement with the observation carried out by Kalita and Rath (1996) in male Notopterus notopterus. Similar conditions were noticed in Ompok bimaculatus (Sivakami, 1987), Rasbora daniconius (Sunil, 2000) and Chela untrahi (Kiran, 2002). The divergence from cube law may be due to certain environmental factors also. The value of exponent (b) in the equation $\mathrm{W}=\mathrm{aL}^{\mathrm{b}}$ (LeCren, 1951) generally is nearer to 3 (Allen, 1938) or between 2.5 and 4.0 (Martin, 1949). The present value ranged between 2.8483 and 3.2721. In Rita rita (Devi et al., 1991) and Labeo rohita (Sakar et al., 1999) similar values have been reported earlier. 


\section{REFERENCES}

Allen, K.R. (1938). Some observations on the biology of the trout (Salmo trutta) in Windermere. Journal of Animal Ecology 7: 333-349.

Choudhary, D.K., P.S. Choudhary and Chhatbar (1975). A preliminary study of some morphometric characters of Hilsa Sinensis (L.). Association, CIFA, Souvenir 1: 32-34.

Devi, T.N., F. Khumar and M.S. Siddiqui (1991). Observations on the morphometric characters of the Catfish, Rita rita (Hamilton) from the River Yamuna in North India. Journal of Inland Fisheries Society of India 23(1): 52-58.

Hamza, A.E. (1980). Studies on certain aspects on biology and reproduction of genus Notopterus. Ph.D. Thesis, Culcutta University, Calcutta, India (Unpublished).

Kalita, K. and R.K. Rath (1996). Length-weight relationship of male Notopterus notopterus (Pallas). Journal of Environment and Ecology 14(4): 983-984.

Kiran, B.R. (2002). Studies on the biology of Chela untrahi of Bhadra Reservoir. Ph.D. Thesis, Kuvempu University, India (Unpublished).

LeCren, E.D. (1951). The length-weight relationship and seasonal cycle in gonad weight and condition in the Perch (Perca fluviatilis). Journal of Animal Ecology 20: 210-219.

Martin, W.R. (1949). The mechanics of environmental control of body form in fishes. Toronto University of Biological Studies 58: 1-91.

Parameswaran, S. and M. Sinha (1966). Observation on the biology of the featherback Notopterus notopterus (Pallas). Indian Journal of Fisheries 13: 232-250.

Pauly, D. (1983). Some simple methods for the assessment of tropical fish stocks. FAO Fisheries Technical Paper 234: 1-52.

Sarkar, S.K., C. Medda, S. Ganguly and T.K. Basu (1999). Lengthweight relationship and relative condition of bundh and hatchery bred Labeo rohita (Hamilton) during the early period of development. In: de Silva, S.S (editor). Proceedings of the Asian Fisheries Society, Manila, Phillippines. Asian Fisheries Science 12: 289-296.

Sivakami, S. (1987). Length-weight relationship and relative condition in Ompok bimaculatus (Bloch) from Bhavanisagar Reservoir (Tamil Nadu). Indian Journal of Fisheries 34: 136-140.

Sunil, M.S. (2000). Length-weight relationship in Rasbora daniconius (Ham.) from Achancoil River, Pathanamthitta, Kerala, India. Indian Journal of Fisheries 47(3): 271-274.

\section{NESTING OF BLACK IBIS (PSEUDIBIS PAPILLIOSA) IN THAR DESERT OF RAJASTHAN}

\section{Sumit Dookia}

Desert Regional Station, Zoological Survey of India, Jhalamand, Pali Road, Jodhpur, Rajasthan 342005, India.

During several visits to the Thar Desert of Rajasthan, I saw six nests of Black Ibis (Pseudibis papillosa), out of which three nests were reported on a big Pipal (Ficus religiosa) tree in Mukam Village of Bikaner District. Two nests were seen on Pipal tree in Godra villages of Nagpur District and a single nest was located in Rajasthan Agriculture University Campus, Beechwal, Bikaner, again on a Pipal tree.

All nests were present for quite a long time and the local people claimed that the birds use the same tree for nesting every year. Previously, there were no reports of any nesting from this region. Interestingly I observed all nesting trees to be Ficus religiosa. Nair and Vyas (2003) reported its nesting on Ficus bengalensis. Information on the selection of trees especially Ficus for nesting by these birds is not known.

Ali and Ripley (1978) reported that the Black Ibis breed in northern India, later in Gujarat, the Deccan and in the south. Nair and Vyas (2003) reported a nesting pair in Udupuria Village of Kota District. The localities where I observed nesting are quite far from Kota. All new nesting sites are in the Thar Desert of Rajasthan, hence noteworthy.

\section{REFERENCES}

Ali, S. and S.D. Ripley (1978). Handbook of the birds of India and Pakistan. $2^{\text {nd }}$ edition Vol. I. Divers to Hawks. Oxford University Press, London.

Nair, A. and R. Vyas (2003). Nesting record of Black Ibis Pseudibis papilliosa in Kota District, Rajasthan. Zoos' Print Journal 18(3): 1050.

\section{ACKNOWLEDGEMENTS}

I would like to thank Dr. Q.H. Baqri, Officer-in-Charge, Desert Regional Station, Zoological Survey of India for providing financial support, and facilities to conduct the survey works. 